\title{
PENDATANG BARU PASCA KONFLIK SOSIAL TAHUN 1999 DI KOTA AMBON
}

\author{
Fransina Matakena, Syane Matatula \\ Program Studi Sosiologi Fakultas Ilmu Sosial dan Ilmu Politik \\ Universitas Pattimura \\ sien.matakena@gmail.com.syanematatula11@gmail.com
}

\begin{abstract}
Abstrak
Penelitian ini merupakan penelitian kualitatif dengan menggunakan dua pendekatan dalam paradigma kualitatif, penelitian naratif dan penelitian fenomenologi. yang menggambarkan tentang kondisi pendatang yang sudah menetap lama sebelum konflik sosial terjadi di Kota Ambon, dan pendatang yang datang pasca konflik sosial di Kota Ambon. Penelitian ini dilakukan pada negeri Batumerah Kecamatan Sirimau dan Waringin Kelurahan Nusaniwe Kota Ambon. Konsep Hidup Orang Basudara menjadi icon orang Maluku dalam hidup bersama, saling menyatu dalam kehidupan tanpa ada rasa curiga, saling bergandengan menuju hidup yang berdampingan satu dengan yang lain, pendatang lama yang mendiami Kota Ambon bisa berdampingan secara baik dengan masyarakat lokal serta ada dalam harmonisasi hidup orang basudara yang terangkai indah dalam kebersamaan, pendatang baru mengalami kemandekan nilainilai hidup orang basudara karena sulitnya beradaptasi, asimilasi bahkan akulturasi sehingga menimbulkan social distance dalam masyarakat. Hasil penelitian menunjukkan bahwa: Pendatang baru mengalami kesulitan menginternalisasi nilai hidup orang basudara karena pendatang sulit adaptasi yang baik, masih mempertahankan kosmos daerah setempat.
\end{abstract}

Kata Kunci: Konsep Hidup Orang Basudara, Pendatang Baru, Kesulitan Internalisasi.

\begin{abstract}
This qualitative research uses two approaches in a qualitative paradigm, narrative research and phenomenological research, which describes the condition of migrants who had lived long before the social conflict occurred and migrants who come after the social conflict in Ambon City. The research was conducted in Negeri Batu Merah in Sirimau District, and Waringin in Nusaniwe Village, Ambon. The concept of Hidup Orang Basudara (living in brotherhood) has become an icon for the Moluccans in living together, uniting in life without any suspicion, hand in hand towards living side by side with one another. Old migrants who inhabit Ambon city can coexist well with the local community in the harmonization of Hidup Orang Basudara, beautifully arranged in togetherness. Newcomers experience stagnation in the life values of Orang Basudara because of the difficulty of adapting, assimilation, and even acculturation, causing social distance in community. The study results show that newcomers have difficulty internalizing the values of Hidup Orang Basudara because they are difficult to adapt well and still maintain their local cosmos.
\end{abstract}

Keywords: Living in Brotherhood Concept, Newcomer, Internalization Difficulty 


\section{Pendahuluan.}

Migrasi merupakan suatu aktivitas pindahnya seseorang sedangkan orangnya yang pindah tempat tinggal disebut Migran. Menurut Castles 2015 migrasi tidak dapat dijelaskan sebagai hasil transformasi sosial, tetapi harus dikatakan sebagai bagian dari proses transformasi sosial, karena mobilitas manusia tidak terlepas dari perubahan dalam masyarakat, praktik dan institusi politik, budaya,sosial, ekonomi. Pendatang yang ada di Kota Ambon ini juga ada yang berasal dari luar Maluku seperti mereka yang berasal dari Pulau Jawa, Sulawesi, Bali, Kalimantan dan sebagainya, sedangkan migran lokal yang ada juga berasal dari Maluku, berasal dari Kepulauan Kei, Maluku Barat Daya, Maluku Tenggara Barat, Pulau Lease,dan Pulau Buru. Di sisi lain, program transmigrasi maupun migrasi yang dilakukan sering berkontribusi bagi gaya hidup dan praktik gaya budaya yang baru bukan dipandang sebagai asimilasi, tetapi lebih tepat disebut sebagai konstruksi identitas baru yang tidak menolak budaya dominan dan tetap mempertahankan budaya migran itu sendiri (Degia 2006), jika para transmigran atau migran mampu mengorganisir kapasitas masyarakat penerima maka program transmigrasi maupun migrasi dapat menjadi berkelanjutan.

Akibat migran yang datang dari berbagai daerah ini menyebabkan mereka ada dalam posisi tempat tinggal yang tersegregasi (segregated pluralism) menurut suku dan juga agama yang mereka anut. Menurut T.Soumokil ( 2011). Mobilisasi penduduk yang berasal dari luar Maluku khususnya dikota Ambon pasca konflik cenderung tersegregasi menurut suku dan agama, terlihat dengan lokasi tempat tinggal yang ditempati oleh migran. Kondisi sosial yang terjadi pasca konflik di Kota Ambon banyak migran khususnya yang berasal dari Buton dan Bugis Makassar untuk memilih tempat tinggal dekat dengan pusat kota telah membawa perubahan pada ekosistem kota Ambon, tujuan mereka supaya mudah melakukan transaksi di pasar dengan variasi pekerjaan mereka sebagai pedagang (pedagang makanan,maupun pakaian). Menurut Farhadian, Charles E. (2005). Program transmigrasi ini mengakibatkan perseteruan antara suku yang mengenal satu sama lain lewat transmigrasi. Semakin kuat jaringan sosial etnis para migran semakin memudahkan urusan sosial ekonomi, terutama untuk mendapatkan pekerjaan di kota (Atiyatul Izzah. 2011) Sulitnya pendatang baru yang datang ke Kota Ambon pasca konflik untuk beradaptasi dengan masyarakat lokal disebabkan oleh beberapa hal antara lain, kurang adaptasi pendatang baru dengan masyarakat lokal dengan kurangnya relasi yang 
baik dalam menyatukan kosmos mereka dengan kosmos masyarakat lokal. Masyarakat pendatang baru (migran pasca konflik) di kota Ambon memiliki konsep dan keterikatan kosmologi yang berbeda-beda menurut habitas dan habituasinya masing-masing. Ada yang berbasis etnis, pulau, ada pula yang berbasis agama dengan keterikatan subyektif yang intens. Kosmos pendatang masih berpusat pada kosmos asalnya dan belum terakomodasi secara total dengan kosmologi penduduk asli kota Ambon. Demikian juga dengan habitus yang masih dibawa mengendap lama dalam kehidupan mereka sehingga sulit untuk mencair dengan masyarakat lokal.

Ravenstein (1885) mengungkapkan dalam hukum migrasinya bahwa jarak yang semakin jauh maka volume migrasi makin berkurang, migrasi akan mengarah ke daerahdaerah pusat industri dan perdagangan, setiap arus balik utama menimbulkan arus balik sebagai penggantinya. Sulitnya pendatang baru yang datang ke Kota Ambon pasca konflik untuk beradaptasi dengan masyarakat lokal disebabkan oleh beberapa hal antara lain, kurang menyatunya pendatang baru dengan masyarakat lokal dengan kurangnya relasi yang baik dalam menyatukan kosmos mereka dengan kosmos masyarakat lokal. Masyarakat pendatang baru (migran pasca konflik) di kota Ambon memiliki konsep dan keterikatan kosmologi yang berbeda-beda menurut habitas dan habituasinya masingmasing. Ada yang berbasis etnis, pulau, ada pula yang berbasis agama dengan keterikatan subyektif yang intens. Kosmos pendatang masih berpusat pada kosmos asalnya dan belum terakomodasi secara total dengan kosmologi penduduk asli kota Ambon. Pendatang (migran) pascakonflik masih terikat dengan habitat dan kosmos asalnya sehingga tercipta jarak sosial (social distance) antara pendatang pasca konflik dan penduduk asli (termasuk migran yang telah menjadi Orang Basudara atau Orang Ambon sebelum konflik). Hal mana dijelaskan oleh beberapa migran sebelum konflik dalam hasil penelitian Watloly dkk (2017). Migran pascakonflik hanya memiliki motivasi ekonomi dan politik. Mereka ingin memanfaatkan kelemahan hukum dan ketidakpastian sosial untuk mendapatkan fasilitas pengungsi, usaha dan kerja tanpa menaruh perhatian dan cinta akan kaidah hidup Orang Basudara, tapi juga kerawanan sosial pada beberapa lokasi migran di kota Ambon, seperti; di Waringin (daerah muslim dan juga Kristen dengan berbagai komunias asal Maluku maupun migran nasional) Batumerah (daerah Muslim dengan berbagai komunitas asal Maluku maupun migran nasional), yang akan menjadi lokasi penelitian ini. 


\section{Metode Penelitian.}

Penelitian kualitatif adalah aktivitas pada suatu lokasi yang menempatkan peneliti dalam dunia tersendiri yang terdiri dari rangkaian paktek material interpretatif dan membuat dunia disaksikan menjadi serangkaian representatif, melalui catatan lapangan, wawancara percakapan, foto dan rekaman serta memo tentang diri (Denzin dan Linclon 2011:3) Penelitian fenomenologi Creswell (2007), sangat kental dengan pengalaman peneliti di lapangan dalam memahami fenomena di lokasi penelitian. Dalam penelitian fenomenologi, peneliti diharuskan untuk memahami dua gambaran yang bersifat tekstural dan struktural. Selain data primer yang di ambil ada juga data sekunder yang diambil. Data sekunder yang digunakan bertolak pada metode yang diterapkan Harper (2004), terkait sosiologi visual yang menggunakan gambar melalui kamera. Harper menjelaskan foto atau gambar (image) dapat melengkapi ketidaksetaraan antara observasi dan wawancara

\section{Temuan dan Pembahasan.}

Dalam memahami keharmonisan yang terjadi antara masyarakat yang multikultur ini maka ada jarak yang terimplementasi dalam disharmoni antara pendatang dan masyarakat lokal, seperti terlihat pada tabel dibawah ini:

Tabel 1: Disharmoni Hidup Orang Basudara

\begin{tabular}{|l|l|}
\hline Masyarakat Lokal & Pendatang Baru \\
\hline - Konsep hidup Orang & - Tidak/kurang \\
Basudara & beradaptasi \\
- Ale Rasa Beta Rasa & - Masih membawa \\
- Potong dikuku rasa & kosmos budaya \\
didaging & setempat \\
- Sagu salempeng bage & \\
dua & \\
\hline
\end{tabular}

Masyarakat lokal yang ada dalam kehidupan bermasyarakat memiliki konsep hidup Orang Basudara yang sudah ada sejak lama dan sudah mengakar pada kehidupan keseharian, dengan kehidupan yang saling care (perhatian) antara satu dengan yang lain, memberikan rasa sepenanggungan dalam susah maupun senang dalam setiap situasi yang dihadapi. Konsep masyarakat lokal dipahami sebagai masyarakat basudara dengan terminologi orang basudara sebagai satu kesatuan yang tak terpisahkan antara satu dengan 
yang lain dalam kehidupan keseharian yang saling peduli (care), saling bakubantu antara satu dengan yang lain dan sebagainya.

\section{a. Masyarakat Lokal, Konsep Hidup Orang Basudara}

Local wisdom yang ada dalam masyarakat kota Ambon yang terangkum dalam budaya hidup orang basudara selalu memuat nilai-nilai Hidup Orang Basudara yang ada didalamnya sebagai strategi yang melahirkan perdamaian tanpa ada konflik dan perseteruan dan berfungsi untuk memberikan rasa aman dalam kehidupan.

\section{Gambar 1. Konsep Hidup Orang Basudara}
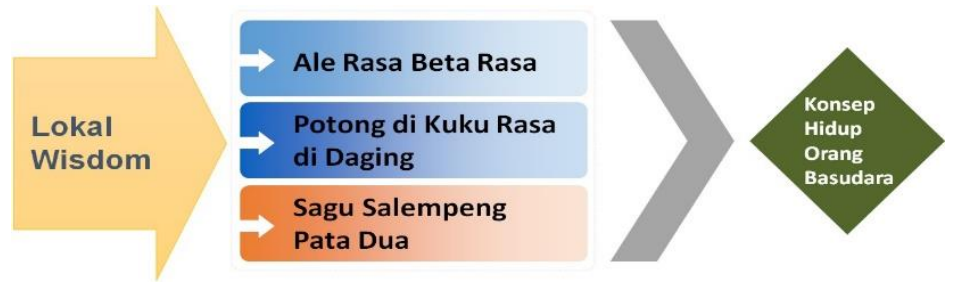

\section{- Ale Rasa Beta Rasa}

Konsep "Ale rasa beta rasa" menjadi sebuah wacana dalam diskursus Hidop Orang Basudara dari waktu ke waktu dalam setiap lintasan sejarah anak negeri Maluku. Falsafah Ale Rasa Beta Rasa menjadi sebuah vocal harmoni yang luhur, mulia dan suci (sakral) dalam perspektif local (perpective indigenous) anak negeri Maluku yang adatis. Ia bukan sekedar menjadi pelengkap kata dalam sistem pewacanaan hidup orang Maluku, tetapi dasar hakiki bagi Hidop Orang Basudara. Hal mana mengindikasikan bahwa Vocal Ale Rasa Beta Rasa dalam konsep Orang Basudara di Maluku mengandung nilai-nilai kearifan atau nilai-nilai filosofis yang kaya, baik dalam sistim pemikiran maupun dalam lakon hidup anak negeri Maluku, yang majemuk baik dari sisi pulau, bahasa, agama maupun tradisi hidup. Ale Rasa Beta Rasa menandai cita rasa dua subyek (aktor) yang berpadu rasa dalam pola hidup saling seperasaan dan sepenanggungan, yaitu Ale (anda) dan Beta (saya) yang berpadu hidup dalam satu rasa, yaitu rasa Hidup Orang Basudara. Sebuah solidaritas yang benar-benar luhur mulia dan sakral. Hal mana, misalnya dapat diamati di dalam pola kehidupan berbagai negeri adat yang saling memiliki hubungan persaudaraan seperti Pela atau Gandong di Maluku Tengah. Ale Rasa Beta Rasa dalam menjalani arus kehidupan yang terbuka. Dengan semangat hidup yang dilandasi oleh kasih yang tulus tanpa memandang perbedaan agama telah menyatukan hidup bersama. Ale dan 
Beta sebagai pasangan yang harmoni, rasa yang menyambung hati dan jiwa dua insan yang berbeda, rasa sebagai vokal perdamaian dan rasa sebagai rasio sosial orang basudara. (Watloly dan Matakena, 2013)

Istilah Ale Rasa Beta Rasa dalam Konsep Orang Basudara Di Maluku mengandung nilai-nilai kearifan atau nilai-nilai filosofis yang kaya, baik dalam sistim pemikiran maupun dalam lakon hidup anak negeri Maluku, yang majemuk baik dari sisi pulau, bahasa, agama maupun tradisi hidup. Ale Rasa Beta Rasa menandai cita rasa dua subyek (aktor) yang berpadu rasa dalam pola hidup saling seperasaan dan sepenanggungan, yaitu Ale (anda) dan Beta (saya) yang berpadu hidup dalam satu rasa, yaitu rasa Hidup Orang Basudara. Sebuah solidaritas yang benar-benar luhur mulia dan sakral.

\section{- $\quad$ Potong di kuku Rasa di Daging}

Konsep potong dikuku rasa di daging memberikan makna positif yang terkandung dalam ungkapan diatas, setiap anak Maluku yang berbeda teritori dan sama teritori memiliki persamaan yang hakiki didalamnya, perkembangan selanjutnya dalam berkomunikasi akan lebih terasa dengan istilah potong di kuku rasa di daging yang merupakan dua subjek yang tak bisa dipisahkan dalam kehidupan bersama sebagai orang basudara. Ketika ada persoalan kehidupan yang membuat kehidupan ini merasa senang maka akan dirasakan senang juga dengan saudara yang merasa senang saat itu, dan ketika ada dalam kedukaan maka rasa itu juga sama dirasakan oleh saudara sebagai satu kesatuan hati yang tidak bisa terpisahkan dari kehidupan ini, menurut informan (masyarakat lokal) potong dikuku rasa didaging merupakan suatu pertautan antara cinta yang tak bisa terpisahkan antara satu dengan yang lainnya, yang sinergis dalam posisi yang saling memahami akan situasi dan kondisi kenyamanan antara dua makhluk yang berbeda, saling mengerti dalam situasi susah maupun senang, arti potong di kuku rasa di daging benar dirasakan menyatukan perasaan dalam satu keutuhan orang basudara.

\section{- Sagu Salempeng Patah Dua}

Sagu salempeng patah dua adalah akar dari falsafah hidup orang basudara di Maluku yang mencerminkan sikap dan batin dari orang Maluku. Semangat yang melibatkan orang basudara dan merupakan energi budaya untuk mampu membina hidup bersama yang terlihat apik dan menarik serta harmonis dalam perbedaan yang mendasar. Hal inilah yang membuat Maluku menjadi masyarakat yang besar yang terintegrasi dalam 
satu keluarga yang multikultur. Sagu merupakan makanan khas masyarakat Maluku yang biasa ada pada setiap keluarga yang mencintai produk lokal dan mampu memberikan nuansa persatuan yang hakiki dalam perbedaan sehingga harmonis dan menarik dalam keseharian kehidupan masyarakat. Makanan ini sering diolah dengan berbagai ragam dan bentuk, kalau di Ambon ada yang biasa disebut dengan sagu lempeng, rasanya tidak ada namun enak dimakan pada saat pagi hari atau sore hari dengan cara dicelup kedalam secangkir teh atau kopi dan dimakan dengan kacang goreng, selain itu ada juga olahan sagu yang berbentuk sagu mentah yang dituang untuk dijadikan papeda dan enak dimakan dengan kuah ikan kuning atau yang sejenisnya, dan masih banyak olahan kue sagu yang memiliki bahan dasarnya sagu dengan berbagai variant dan rasa, seperti kue makron, serut, sagu tumbuk, sagu keju, coklat dan lain sebagainya yang sangat cocok untuk dijadikan oleh-oleh ketika mengunjungi kota Ambon. Makna sagu salempeng dipatah dua memberikan nuansa yang hampir sama dengan kedua konsep orang basudara diatas, Ale Rasa Beta Rasa, dan Potong dikuku Rasa di daging yang memberikan arti konotasi dalam menyikapi kehidupan ini secara bersama dalam suka maupun dalam duka.

Pendatang baru mengalami kesulitan untuk mengintenalisasi nilai-nilai hidup orang basudara dan terjadi disharmoni dalam kehidupan bermasyarakat artinya makna slogan diatas menjadi sulit untuk dijadikan sebagai budaya yang mesti menjadi budaya bersama dalam kehidupan masyarakat kota Ambon yang melibatkan seluruh komponen masyarakat.

\section{- Pendatang Baru Dalam Konsep Hidup Orang Basudara}

Pendatang baru yang mendiami kota Ambon dalam hal ini mereka yang berasal dari beberapa suku di Indonesia memposisikan diri mereka sebagai orang baru dalam kawasan tempat tinggal maupun tempat bekerja, artinya kesatuan diri dalam integrasi sosial terlihat kurang nampak dalam pergaulan maupun aktifitas mereka seperti terlihat pada gambar berikut ini

Gambar 2. Sulit Internalisasi

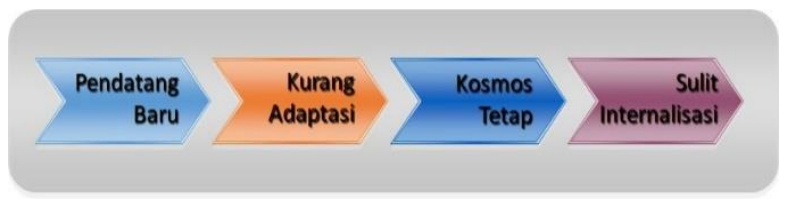




\section{- Kurang Adaptasi}

Bagian terpenting dalam kehidupan bersama secara integrasi memerlukan proses adaptasi, adaptasi biasanya terjadi dalam kehidupan makhluk hidup yang membutuhkan makhluk lain disekelilingnya untuk bisa bertahan hidup dengan habitatnya, demikian juga manusia memerlukan adaptasi dengan lingkungan sosial dimana dia berada. George Ritzer (2008) menjelaskan konsep AGIL yang dikemukakan oleh Talcot Parsons mengenai Adaptation, Goal Atattement, Integration dan Latency, yang mana point Adaptation merupakan suatu proses yang dilakukan oleh manusia pada fase penyesuaian diri dengan lingkungan dimana dia berada, proses ini adalah suatu sistem yang membutuhkan kerjasama antara culture dan berbagai bidang lainnya yang menghasilkan keberhasilan dari sistem yang ada dalam masyarakat. Menurut teori fungsionalis masyarakat "suatu sistem sosial yang terdiri dari bagian-bagian atau elemen saling berkaitan dan saling menyatu dalam kesimbangan". Jika terjadi perubahan pada bagian yang satu maka akan terjadi perubahan juga pada bagian yang lainnya. Masyarakat dilihat sebagai sebuah sistem yang terintegrasi menjadi satu, masing-masing mempunyai fungsi yang berbedabeda namun saling berkaitan dan menciptakan konsensus serta keteraturan sosial. Secara umum adaptasi merupakan sistem yang bisa mengatasi kebutuhan situasional yang datang dari luar, mampu menyesuaikan diri dengan lingkungan serta berbagai kebutuhannya.

Pendatang baru yang mendiami dua lokasi penelitian terlihat kurang beradaptasi dengan lingkungan yang ada di sekitar tempat tinggal mereka, perhatiannya hanya tertuju pada bidang ekonomi yang bisa memberikan kenyamanan secara financial dalam memenuhi kebutuhan setiap hari, toleransi yang dilakukan dalam kehidupan mereka ada dalam kebersamaan namun sebenarnya tidak mengikuti apa yang diinginkan untuk melakukan hidup yang wajar sebagai orang basudara dalam kehidupan kesehariannya, pada saat kerjabakti misalnya, hanyalah sebatas material yang diberikan sebagai tanda partisipasi nyata dalam hidup bermasyarakat yang dibangun, pada saat kondangan, mereka jarang menghadiri acara seperti itu, disharmoni yang terbangun memberikan rasa ketidakpedulian terhadap lingkungan yang ada disekitar kehidupan mereka sebagai pendatang, sehingga kehidupan bersama dalam merajut hidup orang basudara yang terpatri selama ini kurang memberikan rasa simpatik maupun dalam perilaku yang ditunjukkan sebagai wujud kehidupan bersama. 


\section{- Masih Membawa Kosmos Setempat}

Karena beberapa hal, pendatang baru merasa bahwa nilai orang basudara itu tidak penting dalam kehidupan mereka karena yang mereka perlukan dalam kehidupan ini hanyalah bagaimana mencari nafkah untuk kebutuhan kehidupan mereka sehari-hari seperti yang terlihat dalam hasil wawancara beberapa informan yang didapati dilokasi penelitian. Nilai adaptasi yang sulit dilakukan karena untuk menyatukan dua budaya yang berbeda agak sulit, dialek yang masih tetap dipertahankan dalam situasi komunikasi yang dilakukan setiap saat, proses interaksi yang dibangun dalam komunitas yang berbeda basic ini agak sulit untuk dileburkan untuk menyatu, dalam pemahaman dialek yang agak sulit untuk diselami antara satu dengan lainnya, bahkan kosmologi yang masih dibawa dalam kehidupan keseharian masih mencerminkan kosmos dari daerah asal mereka sebagai suatu cultur yang tak mungkin dilupakan begitu saja, ditambah lagi dengan budaya lokal yang melekat dengan kehidupan keluarga yang terus dilestarikan dalam segala moment yang terjadi di Maluku seperti perayaan-perayaan yang melibatkan berbagai unsur kesenian, selain itu ada juga perhimpunan paguyuban dan juga ikatan masyarakat sulawesi (KKSS) yang terhimpun dalam kota Ambon yang melibatkan para migran secara menyeluruh.

Hambatan dan tantangan yang dihadapi memberikan rasa takut dalam menghadapi kenyataan kehidupan. Masalah yang sulit untuk menginternalisasi masyarakat pendatang baru pasca konflik adalah mengikuti berbagai kegiatan kebudayaan yang sulit dpahami dengan budaya lokal, seperti tarian yang menggambarkan keras kehidupan dengan menggunakan parang dan salawaku, budaya yang menggunakan tenaga yang kuat dalam menyikapi berbagai acara dengan lomba panggayo manggurebe maju, selain itu karakter masyarakat yang agak keras menyulitkan pendatang untuk bisa beradaptasi dengan budaya lokal setempat. Kemandekan yang dialami oleh pendatang baru dalam menginteranlisasi nilai hidup orang basudara, terlihat pada hasil wawancara yang dilakukan bahwa kehidupan boleh berlangsung di sini namun budaya yang dibawa dari tempat asal akan tetap diwariskan kepada generasi berikutnya, hal seperti ini yang membuat sulit untuk pendatang ada dalam internalisasi hidup orang basudara. 


\section{Kesimpulan.}

Sulitnya internalisasi nilai hidup orang basudara disebabkan kurang beradaptasinya pendatang melalui interaksi, selain itu pengalaman interaksi antara pendatang dengan masyarakat lokal merasa ragu-ragu, takut, curiga serta kurangnya pengetahuan tentang nilai orang basudara yang mengakibatkan kerenggangan sosial. Pendatang masih membawa habitus yang sudah mengendap lama dari daerah asalnya sehingga menyulitkan penyatuan konsep hidup basudara dan hal ini yang menimbulkan jarak sosial antara satu dengan lainnya. Pendatang baru masih membawa kosmos setempat sehingga sulit untuk membaur pada kedua komunitas.

\section{Daftar Pustaka.}

Amanda, R. (2017). Hubungan Antara Prasangka Masyarakat Terhadap Muslimah Bercadar Dengan Jarak Sosial. Jurnal RAP, 5(1).

Andi Agustang, 2015. Dasar-Dasar Penelitian untuk Pengembangan Ilmu. Makassar. CV. Multi Global

Anthony Giddens, Daniel Bell, Michel Force,etc, 2005, Sosiologi sejarah dan Berbagai Pemikirannya. Kreasi Wacana Yogyakarta.

Arsip Kantor Batumerah tahun 2010.

Baron dan Paulus. 2009. Social Psychology. Jakarta:Erlangga

Basrowi dan Sudikin. 2002. Metode Penelitian Kualitatif Mikro, Surabaya: Insan Cendekia.

Bedford, R. 1981. Variety and Form of Population Mobility in Southeast Asia and Melanesia: The Case of Circulation. Canberra: Australian National University.

Berger P. L. dan Lukman T. 1990. Tafsir Sosial Atas Kenyataan. Risalah tentang Sosiologi Pengetahuan. Penerjemah Hasan Basari. LP3ES. Jakarta

Blumer, Herbert (1969). Symbolic Interaction: Perspective and Method, Englewood Cliffs, Prentice Hall, New York.

Castles,Stephen, 2015. "International Human Mobility: Key Issues and Challenges to Social TheoryThe Power Identity", Social Transformation and Migration National and Local Experiences in South Korea,Turkey. Mexico and Australia, New York: PalgraveMacmillan

Creswell, John, W. 2007. Qualitative Inquiry \& Research Design: Choosing Among Five Approaches $2^{\text {nd }}$ edition. London: Sage Publications 
Degia, Haajima. 2016. "Identity Construction of an Ethno-Religious Group in Barbados: The Case of Gujarati-Muslims", Journal of Eastern Carribean Studies Vol 41 (1), pp 47-82

Denzin Norman \& Linclon, 2011. Handbook of Qulitative Research. Terjemahan Dariyanto, Samsul Bardus F, Abi, Rinaldi. Jakarta Pustaka Pelajar.

Farhadian, Charles E. (2005). Christianity, Islam, and Nationalism in Indonesia. Taylor $\underline{\text { \& Francis }}$

George Ritzer - Douglas J. Goodman, 2008. Teori Sosiologi Modern. Jakarta Kencana

Harper, Douglas. 2004. "Photography as Social Science Data", A Companion to Qualitative Research. London: Sage Publications

Izzah, Atiyatul 2011, Jaringan Sosial dn Variasi Pekerjaan Para Migran di Kota Samarinda. Masyarakat Jurnal Sosiologi, Vol.16, No. 2.

Soumokil. Tontji. 2011. Reintegrasi Sosial Pasca Konflik Maluku. Salatiga Universitas Kristen Satya Wacana. Press

Watloly Aholiab dan Fransina Matakena 2013. Ale Rasa Beta Rasa Dalam Konsep Hidup Orang Basudara Di Maluku. Kementerian Pendidikan dan Kebudayaan Balai Pelestarian Nilai Budaya Ambon. 